http://dergipark.gov.tr/ataunizfd

\title{
İzmir İli Menderes İlçesinde Kesme Çiçek Üreticilerinin Üretim Kararlarını Etkileyen Faktörler
}

\author{
Sefa BARLAS ${ }^{(i)}$ M. Çağla ÖRMECI KART ${ }^{*}$ Filiz KINIKLI ${ }^{(i)}$ Şule IŞIN \\ Ege Üniversitesi, Ziraat Fakültesi, Tarım Ekonomisi Bölümü, Bornova, İzmir, Türkiye \\ (*Sorumlu yazar e-mail: cagla.kart@ege.edu.tr) \\ DOI: 10.17097/ataunizfd.532992
}

Geliş Tarihi (Received Date): 27.02.2019

Kabul Tarihi (Accepted Date): 16.07.2019

\begin{abstract}
ÖZ: Son yıllarda, kesme çiçek üretimi ve ihracatı birçok ülkenin ekonomisinde büyük bir role sahiptir. Kesme çiçek endüstrisi, hem dünyada hem de Türkiye'de üretim ve ticaret hacmi ile önemli bir ekonomik aktivite olarak ilerlemesini sürdürmektedir. Kesme çiçek talebindeki artış ve ulaştırma hizmetlerindeki gelişmeler bu sektörün ilerlemesini hızlandırmıştır. Bu araştırma İzmir ili Menderes ilçesi Altıntepe mahallesinde seçilen gül, gerbera, karanfil, krizantem, lisiantus üreticilerini kapsamaktadır. Kesme çiçek üreticilerinin sosyo-ekonomik yapısı, üretim ekonomisi ve işletmelerin yıllık faaliyet sonuçları incelenmiş ve sonuçlar sunulmuştur. Her kesme çiçek için toplam brüt üretim değerleri, değisşen masraflar, brüt kârları ve birim maliyetler hesaplanmıştır. Sonuçlara göre; karanfil üretimi, diğer kesme çiçek türleri arasında en kârlı olarak tespit edilmiştir. Ayrıca, karanfil üretim kararını etkileyen en önemli faktörler 'üretim masraflarının az olması ve alışkanlıklar' olarak saptanmıştır.
\end{abstract}

Anahtar kelimeler: Karanfil, Gül, Gerbera, Kasımpatı, Best-worst analizi

Factors Affecting The Production Decisions of Cut Flowers Producers in Menderes Region of Izmir Province

\begin{abstract}
Recently, cut-flowers production and export has a great role in economies of many countries. The industry of cut flower continues its progress as an important economic activity with its volume of production and trade both in the world and in Turkey. The increase in demands for cut flowers and the developments in transportation services have recently accelerated the progress of the industry. This research covers a group of selected farmers producing rose, gerbera, carnation, chrysanthemum, lisiantus in Altıntepe neighborhood in Menderes district in Izmir province. Economics of cut-flowers production, socio-economic structure and annual activity results of the farms were examined and results were represented. For each cut flower, total gross production values, variable costs, gross margins, and unit costs were also calculated. According to results; carnation production is found the most profitable among the other cut-flowers types. Besides, it was determined that 'low production costs and habits' are the most important factors affecting carnation production decisions.
\end{abstract}

Keywords: Carnation, Rose, Gerbera, Chrysanthemum, Best-worst analysis

\section{GíRiş}

Süs bitkileri genel bir kavram olup; kesme çiçekler, iç mekân (saksıl1-salon) bitkileri, dış mekân bitkileri, doğal çiçek soğanları olmak üzere 4 grup altında incelenmektedir (Aksu, 2001). Kesme çiçekler; dünyada ticareti en fazla yapılan süs bitkileri grubu olarak görülmektedir. Kitlesel üretim yapılabilmesi ve taşınmalarının kolay oluşu bu ürünlerin ticaretini de kolaylaştırmaktadır. Kesme çiçek kavramı genellikle buket, sepet, çelenk ve aranjmanlarda kullanılan, çiçek, gonca, dal ve yaprakların taze, kurutulmuş, boyanmış veya ağartılmış olarak kullanıma sunulmuş durumlarını ifade etmektedir (Akpınar ve Bulut, 2006).

Dünyada kesme çiçek üretimi 20. yüzyıl başlarında önem kazanmaya başlamıştır ve günümüzde 50'den fazla ülkede kesme çiçek üretimi yapılmaktadır (Tutar, 2011). Türkiye dünya kesme çiçek üretiminde yaklaşı $\% 0.2$ 'lik bir paya sahiptir. Türkiye'de ticari anlamda kesme çiçek üretimi; 1940'l y1llarda İstanbul ve çevresinde başlamış, Yalova önemli bir üretim merkezi konumuna gelmiş ve daha sonra Antalya'da ve İzmir'de üretim yapılmaya başlanmıştır. 1945 yılında üreticilerin bir araya gelerek "Sınırlı Sorumlu Çiçek Üretim ve Pazarlama Kooperatifi"ni (FLORA) kurmalarıyla bölgede çiçekçilik hızla gelişmiştir. 1975'de önemli bir gelişme olmuş ve ulaşım olanaklarındaki artış İstanbul dışında ilk kez İzmir'de üretimin başlanmasını sağlamıştır (Hazar ve Baktır 2016). Sektörün büyümesi ihracat teşvikleri ve çoğaltma materyali ithaline kolaylıklar getirilen 1985 yılına kadar sınırlı olmuş, bu yıldan sonra ise tüm faaliyet alanlarında çok hızlı gelişmeler yaşanmıştır (Açıl ve Demirci, 1984). Türkiye'de kesme çiçek üretiminin gelişmesinde uluslararası kuruluşlarla işbirliğinin de büyük katkısı olmuştur. 1970'li ve 1980'li yıllarda, FAO (Birleşmiş Milletler Gıda ve Tarım Örgütü) ve Dünya Bankası kesme çiçek üretiminin gelişmesini sağlamak için çeşitli araştırma projelerini desteklemişlerdir. Bunlardan birisi FAO tarafindan desteklenen ve 1973-1976 yılları arasında Atatürk Bahçe Külttürleri Enstitüsü öncülüğünde yürütülen "Türkiye'de Çiçekçiliğgi Geliştirme Projesi'dir. Proje ile bazı yeni çiçek türlerinin üretilmesi, yeni üretim tekniklerinin geliştirilmesi ve bazı türlerde üretim materyali ihtiyaçlarının karşılanması sağlanmıştır (Aksu vd., 2016).

Türkiye'de kesme çiçek faaliyet alanında yıllardır süregelen ikili bir yapının varlığı söz konusudur. Yapılardan biri nispeten ileri teknoloji kullanan, geniş 
üretim alanlarına sahip daha profesyonel pazarlama sistemleri ile ihracata yönelik üretim yapan işletmeler, diğeri ise teknolojik yatırım yeteneği düşük sınırlı alanlarda aile işletmesi şeklinde üretim yapan ve ürünlerini büyük oranda kooperatifler kanalıyla pazarlayan iç pazara yönelik üretim yapan işletmelerdir (Özkan ve Karagüzel, 1997).

Ülkemizde yaklaşık 52 bin dekarda süs bitkileri üretimi yapılmakta olup, üretim alanının \%70'i dış mekan süs bitkileri, \%26'sı kesme çiçek, \%3.2'si iç mekan süs bitkileri, $\% 0.80$ 'i ise çiçek soğanları yetiştiriciliğine ayrılmıştır. 2017 yılında Türkiye'de kesme çiçek yetiştiriciliği, süs bitkileri alt sektörü içinde üretim miktarı ve değer olarak en büyük paya sahip olan önemli bir faaliyet alanıdır. Ülkemizde kesme çiçek yetiştiriciliği belirli sayıda tür üzerinde yoğunlaşmış olup üretim alanlarının \%36.8'ini karanfil, \%15.9'unu gül, \%8.6'sını gerbera, \%4.9'unu kasımpatı kapsamaktadır. İzmir ilinin kesme çiçek üretim alanları 4159 dekar ile Türkiye kesme çiçek üretim alanlarının \%35.40'ını Menderes ilçesi ise 1603 dekar ile Türkiye kesme çiçek üretim alanlarının \%13.64'ünü oluşturmaktadır. Menderes ilçesinin Türkiye kasımpatı üretim alanındaki payı \%35.83, gül üretim alanındaki payı $\% 35.75$, lisiyantus üretim alanındaki payı \%25.31, karanfil üretim alanındaki payı $\% 6.93$, gerbera üretim alanındaki payı $\% 4.05$ olarak belirlenmiştir. İzmir ili kesme çiçek üretiminde Balçova, Güzelbahçe, Menderes, Seferihisar, Torbalı ve Urla en önemli merkezler olarak karşımıza çıkmaktadır (TUİK, 2018).

Türkiye'nin y1llara göre kesme çiçek üretim miktarları incelendiğinde 2017 yılında kesme çiçek üretim miktarının bir önceki yıla göre $\% 6.5$ oranında artmış olduğu tespit edilmiştir. Türkiye toplam, lisiyantus üretiminin \%34.22'si, kasımpatı üretiminin $\% 25.29$ 'u, gül üretiminin \%20.84'ü, karanfil üretiminin $\% 8.55^{\prime} \mathrm{i}$, gerbera üretiminin $\% 4.70^{\prime} \mathrm{i}$ Menderes ilçesinde gerçekleştirilmiştir (TUİK, 2018). Menderes yöresinde en fazla üretilen kesme çiçek türü karanfil olup bunu gül, kasımpatı, gerbera ve lisiyantus türleri takip etmektedir. Bölgenin uygun iklimsel ve coğrafi koşulları kesme çiçek yetiştiriciliğinde önemli bir merkez olmasını sağlamıştır. Kesme çiçek üretim alanlarının büyük bölümünün bu yörede olması ve üretimin Türkiye bazında önemli bir kısmını oluşturmasından dolayı bu çalışma önem taşımaktadır. Ayrıca Türkiye'de kesme çiçek yetiştiriciliğinin teknik yönü ile ilgili çok sayıda çalışma bulunmasına rağmen kesme çiçek yetiştiriciliğinin ekonomik yönü ile ilgili yapılan çalışmalar oldukça yetersizdir.

Bu çalışmanın amacı, Türkiye'nin kesme çiçek yetiştiriciliğinde önemli üretim bölgelerinden birisi olan Menderes ilçesinde, kesme çiçek üreticilerinin üretim kararlarını analiz ederek, daha kârlı ve daha akılcı tarımsal faaliyette bulunulmasını sağlayacak bir zemin oluşturmaktır. $\mathrm{Bu}$ çerçevede; kesme çiçek işletmecilerinin hangi üretim dallarına yer vereceklerine ilişkin karar verme süreci ve bunu belirleyen faktörlerin saptanması, üreticilerin üretim faaliyetleri sırasında dikkate aldığı hedefler ve bunların önceliklerinin saptanması, planlama çalışmasında kullanmak üzere kesme çiçek türlerine ilişkin verimler, brüt üretim değerleri, değişken masraflar ve brüt marjların (brüt kâr) belirlenmesi hedeflenmiştir. Menderes yöresindeki kesme çiçek üreticilerinin daha rasyonel kararlar alması ve kaynakları rantabl kullanması ile üretim hacminin daha da gelişerek Menderes ve Türkiye ekonomisine önemli katkılar sağlaması beklenmektedir. Ayrıca çalışmadan elde edilecek sonuçlar kesme çiçek yetiştiriciliği yapmak isteyen yatırımcılar için de yararlı bilgiler sunacaktır.

\section{MATERYAL VE METOT}

Bu çalışmanın ana materyalini, İzmir ili Menderes ilçesi Altıntepe mahallesindeki karanfil, gül, lisiyantus, kasımpatı ve gerbera üreticilerinden elde edilen veriler oluşturmaktadır. Veriler, anket formu kullanılarak, üreticilerle karşılıklı görüşme yoluyla elde edilmiştir. Çalışmada ayrıca konu ile ilgili daha önceden hazırlanmış olan araştırma, derleme, inceleme, tez, rapor, makale vb. kaynaklardan yararlanılmıştır. Araştırmada, örnek hacminin belirlenmesinde görüşülecek kişi sayısı aşağıdaki oransal örnek hacmi formülüyle hesaplanmıştır ( Newbold, 1995 ).

$$
n=\frac{N p(1-p)}{(N-1) \sigma_{p x}^{2}+p(1-p)}
$$

$\mathrm{n}$ : Örnek hacmi

$\mathrm{N}$ : İzmir ili Menderes ilçesi ÇKS'ye kayıtlı üretici sayıs1 (365)

$\mathrm{p}=$ Oran (maksimum örnek hacmine ulaşmak için 0.50 alınmıştır)

$$
\sigma_{\hat{p} x}^{2}: \text { Ana Kitle Varyansı }
$$

Örnek hacmi, \%95 güven aralığı ve \%10 hata payı ile 77 olarak hesaplanmıştır. Toplamda 80 üreticiye ulaşılarak anketler tamamlanmıştır. Veri analizlerinde temel tanımlayıcı istatistiklerin yanı sıra, çiftçi görüşleri beşli likert ölçeği yardımıyla alınmıştır. Likert ölçeğinin amacı; araştırılan konuyla ilgili kişilerin düşüncelerini, tutumlarını, davranışlarını bir yelpaze içerisinde sınıflandırmak ya da derecelendirmektir. Likert tipi ölçekten, yanıtlayıcıların araştırma ile ilgili ifadelere ne derece katılıp katılmadığı konusunda bilgi edinmekte yararlanılmaktadır (Arıkan, 2000). Araştırmada üreticilerin kesme çiçek üretimine karar verirken hangi karar mekanizmalarından yararlandığı Best Worst yöntemi ile ortaya konulmuştur. Best Worst yöntemi ilk defa 1980'li y1llarda, Jordan Louviere, Hensher ve Woodworth tarafindan geliştirilen bir ayrık seçim 
modelidir. İlk makale ve yayınlar 1990'ların başlarında ortaya çıkmıştır. Bu yöntemde katılımcılara, bir dizi objeler gösterilir ve onlardan en önemli ve en önemsiz olanlarını göstermeleri istenmektedir (Yavuz vd., 2015).

\section{BULGULAR VE TARTIŞMA}

Görüşülen üreticilerin yaş ortalaması 45.33 yıl, eğitim düzeyi ortalama $6.81 \mathrm{y} 1$, tarımsal üretim deneyimi ortalama 24.01 yıl ve kesme çiçek yetiştiriciliği deneyimi ortalama 16.11 yıl olarak tespit edilmiştir. Görüşülen ailelerin ortalama 4.85 kişilik nüfusa sahip oldukları ve her ailede kesme çiçek yetiştiriciliğinde ortalama 1.36 erkeğin ve 1.11 kadının çalıştığı belirlenmiştir (Çizelge 1).

Tarımda riskleri azaltmanın ve sektörü daha güçlü hale getirmenin yollarından biri üreticilerin örgütlenmesidir. Örgütlenmenin temelini de tarımsal kooperatifler oluşturmaktadır (Yercan ve Kınıklı, 2018). Yörede kesme çiçek üreticileri için sadece S.S.
Flora Çiçekçilik ve Pazarlama Kooperatifinin olduğu saptanmış ve kooperatife üye olan üreticilerin oranı \%96.25 olarak tespit edilmiştir. Bu kooperatif 1946 yılında kurulmuş olup halen 3500 üyesi bulunmaktadır (Akkaya ve Çakıroğlu, 2000). Antalya'da yapılan bir çalışmada ise görüşülen kesme çiçek üreticilerinin kooperatife üyelik oranı $\% 48.50$ olup üye olanların kooperatiften mutlaka bir hizmet aldıkları belirtilmiştir (Taşçığlu ve Sayın, 2005). Yalova ilinde yapılan bir başka çalışmada ise görüşülen işletmelerin \%62.4'ünün bir dernek, birlik veya kooperatife üye olduğu belirtilmiştir (Ay, 2009). Bu sonuçlara göre Menderes yöresinde çiftçilerin örgütlenme oranının çalışma yapılan diğer illere göre daha yüksek olduğu sonucuna ulaşılmaktadır. Kooperatife üye olan üreticilerin kooperatif faaliyetlerinden memnun olma durumu \%77.92 olarak belirlenmiştir. Ayrıca görüşülen kesme çiçek üreticilerinin ÇKS (Çiftçi Kayıt Sistemi)'ye kayıtlı olanların oranı \%92.50 olarak hesaplanmıştır.

Çizelge 1. Kesme çiçek üreticilerinin ve işletmelerin genel özellikleri

\begin{tabular}{lrrrr}
\hline & Ortalama & Standart Sapma & En Küçük & En Büyük \\
\hline Yaş(yıl) & 45.33 & 8.4 & 29 & 68 \\
\hline Eğitim(yıl) & 6.81 & 2.87 & 5 & 16 \\
\hline Tarımsal deneyim(yıl) & 24.01 & 9.73 & 10 & 50 \\
\hline Kesme çiçek deneyimi(yıl) & 16.11 & 10.25 & 1 & 50 \\
\hline Ailedeki birey sayısı & 4.85 & 1.40 & 2.00 & 9.00 \\
\hline $\begin{array}{l}\text { Ailede kesme çiçek yetiştiriciliğinde çalışan erkek } \\
\text { sayısı }\end{array}$ & 1.36 & 0.58 & 1.00 & 4.00 \\
\hline $\begin{array}{l}\text { Ailede kesme çiçek yetiştiriciliğinde çalışan kadın } \\
\text { sayısı }\end{array}$ & 1.11 & 0.48 & 0.00 & 4.00 \\
\hline
\end{tabular}

Çalışmada kesme çiçek üreticilerinin bir sonraki yıl kesme çiçek üretimlerini arttırmayı isteme durumları da incelenmiştir. Buna göre; üretimi artırmayı düşünen üreticilerin oranı \%48.75 olarak belirlenmiştir. Üretimi artırılmak istenen ürünlerden $\% 69.23$ oranla ilk sırayı gül almakta ve gülü \%7.69 oranla karanfil ve gerbera izlemektedir.
Görüşülen üreticilerin en fazla 30 dekar, en az ise 1.50 dekar araziye sahip olduğu saptanmıştır. Üreticilerin toplam arazi varlığı ortalama 6.34 dekar olup bu arazinin 5.49 dekarını seraların kapladığ1 belirlenmiştir. Görüşülen işletmelerde arazi varlığının ortalama 6.19 dekarının mülk ve 0.15 dekarının kira arazi ve ortalama parsel sayısının 1.63 olduğu tespit edilmiştir (Çizelge 2).

Çizelge 2. İncelenen işletmelerin arazi varlığ 1

\begin{tabular}{lccc}
\multicolumn{1}{c}{ Arazi } & Ortalama (Dekar) & En Küçük (Dekar) & En Büyük (Dekar) \\
\hline Mülk & 6.19 & 0.00 & 30.00 \\
\hline Kira & 0.15 & 0.00 & 5.00 \\
\hline Toplam & 6.34 & 1.50 & 30.00 \\
\hline Sulu & 6.13 & 1.50 & 30.00 \\
\hline Kuru & 0.21 & 0.00 & 6.00 \\
\hline Parsel Sayıs1 & 1.63 & 1.00 & 4.00 \\
\hline Sera Alanı & 5.49 & 1.50 & 20.00 \\
\hline
\end{tabular}


Görüşülen üreticilerin en fazla yetiştirdikleri kesme çiçek türü gül olup, gülü; karanfil, gerbera, kasımpatı ve lisiyantus türleri izlemektedir. Üretim alanı olarak durum incelendiğinde ise, ortalama en fazla üretim alanının 5.10 dekar ile gerbera için ayrıldığı görülmüştür. Gerberayı 4.17 dekar üretim alanı ile kasımpatı takip etmektedir. Üretim alanının en az ayrıldı̆̆ 1 kesme çiçek türü ise 2.95 dekar ile karanfildir (Çizelge 3). Yalova ilinde yapılan bir çalışmada incelenen 80 adet kesme çiçek işletmesinde arazi büyüklükleri, lisiyantus için 7.2 dekar ve gül için 121.7 dekar olarak belirtilmiştir (Kızıloğlu vd., 2012).

İncelenen işletmelerde kesme çiçek türlerine göre dekara üretim miktarları ile satış fiyatları çarpılarak, ağırlıklı ortalamalara göre dekara brüt üretim değerleri bulunmuştur.

Karanfil üreticilerinden elde edilen bilgilere göre; y1llik ortalama dekara 167749.72 adet karanfil üretilmektedir. Karanfilin adeti 0.46 TL'ye satılmaktadır. Karanfil üretiminden sağlanan dekara brüt üretim değeri 77164.87 TL olarak hesaplanmıştır. Gül üreticilerinden elde edilen bilgilere göre; yıllık ortalama dekara 56637.46 adet gül üretilmektedir. Gülün adeti 1.00 TL’ye satılmaktadır. Gülün dekara brüt üretim değeri ise 56637.46 TL olarak tespit edilmiştir. Araştırma sonuçlarına göre görüşülen işletmelerde satış fiyatı en yüksek olan ürün gül olarak tespit edilmiştir. Gül ve karanfil haricindeki diğer ürünlerin talebinin az olması da üretimdeki ürün seçimini etkilemektedir. Önemli günlerde daha çok gül ve karanfil tercih edilmesi bu ürünlerin satış fiyatını artırmaktadır. Lisiyantus üreticilerinden elde edilen bilgilere göre; yıllık ortalama dekara 280280.30 adet lisiyantus üretilmektedir. Lisiyantusun adeti 0.20 TL'ye satılmakta olup dekara brüt üretim değeri ise 56056.06 TL olarak saptanmıştır. Dekara üretim en fazla lisiyantustan sağlanmaktadır, ancak lisiyantusun satış fiyatı diğer kesme çiçek türlerine göre oldukça düşüktür. Kasımpatı üreticilerinden elde edilen bilgilere göre ise; y1llık ortalama dekara 99920.06 adet kasımpatı üretilmektedir. Üreticiler, kasımpatının adedini 0.50 TL'ye sattıklarını belirtmişlerdir. Kasımpatının dekara brüt üretim değeri ise 49960.03 TL olarak hesaplanmıştır. Görüşülen gerbera üreticilerinden elde edilen bilgilere göre; yıllık ortalama dekara 83553.06 adet gerbera üretildiği ve gerberanın adetinin 0.49 TL'ye satıldığ 1 tespit edilmiştir. Gerbera üretiminden dekara sağlanan brüt üretim değeri 40941.18 TL'dir (Çizelge 3).

Görüşülen işletmelerde dekara karanfil üretiminin ve karanfil adet satış fiyatının yüksek olması karanfil üretimini en kârlı hale getirmiştir. Ancak araştırma sonuçlarına göre en kârlı üretim karanfil olmasına rağmen üreticilerin en çok gül üretimi yaptığ1 belirlenmiştir.

Çizelge 3. İncelenen işletmelerde ürün deseni, üretim miktarı ve brüt üretim değeri

\begin{tabular}{lccccc}
\multicolumn{1}{c}{ Ürünler } & $\begin{array}{c}\text { Üretici } \\
\text { Sayısı }\end{array}$ & $\begin{array}{c}\text { Üretim Alanı } \\
\text { (Dekar) }\end{array}$ & $\begin{array}{c}\text { Üretilen-Satılan } \\
\text { Miktar (Adet daa }\end{array}$ & $\begin{array}{c}\text { Ortalama Satış } \\
\left.\text { Fiyatı (TL adet }^{-1}\right)\end{array}$ & BÜD (TL daa $^{-1}$ ) \\
\hline Karanfil & 22 & 2.95 & 167749.72 & 0.46 & 77164.87 \\
\hline Gül & 49 & 4.03 & 56637.46 & 1.00 & 56637.46 \\
\hline Gerbera & 10 & 5.10 & 83553.43 & 0.49 & 40941.18 \\
\hline Kasımpatı & 6 & 4.17 & 99920.06 & 0.50 & 49960.03 \\
\hline Lisiyantus & 3 & 3.33 & 280280.30 & 0.20 & 56056.06 \\
\hline
\end{tabular}

* Birden fazla ürün üreticisi bulunmaktadır

Kesme çiçek üreticilerinin ürettikleri ürünlere ait değişken masraflar Çizelge 4'de verilmiştir. İncelenen ürünlerde 57604.06 TL ile en fazla değişken masrafa sahip üretim faaliyeti karanfil ve 37567.99 TL ile en az değişken masrafa sahip üretim faaliyeti ise gerbera olarak belirlenmiştir.

İncelenen işletmelerde bir yılda bir dekarda ortalama 167749.72 adet karanfil üretilmektedir ve karanfil üretimindeki toplam masraf dekara 57604.06 TL olarak hesaplanmıştır. Bir adet karanfilin değişken masrafi $0.34 \mathrm{TL}$, ortalama satış fiyatı $0.46 \mathrm{TL}$ ve adet başına sağlanan brüt kâr 0.13 TL olarak saptanmıştır. Karanfil üretiminde değişken masraflar içerisinde en yüksek payın \%49.19 ile işçilik masrafına ait olduğu belirlenmiştir. İşçilik masrafını kimyasal gübre ve ilaç masrafı takip etmektedir. Masraflar içinde en az payın ise organik gübre masrafina ait olduğu görülmektedir. İncelenen işletmelerde dekar başına yıllık ortalama 56637.46 adet gül üretilmekte olup gül üretimindeki toplam masraf dekara 42092.78 TL olarak saptanmıştır. Bir adet gülün değişken masrafının $0.74 \mathrm{TL}$ ve ortalama satış fiyatının $1.00 \mathrm{TL}$ olduğu belirlenmiştir. Gül çiçeği başına sağlanan brüt kâr 0.26 TL olarak hesaplanmıştır. Gül üretiminde değişken masraflar içerisinde en yüksek payı karanfil üretiminde olduğu gibi işçilik masrafı almaktadır. İşçilik masrafını kimyasal gübre masrafi takip etmektedir. Masraflar içinde en düşük payı ise \%1.26 ile ambalajlama masrafinın aldığı tespit edilmiştir. Görüşülen işletmelerde y1llık ortalama 280280.30 adet lisiyantus üretilmekte olup lisiyantus üretimindeki toplam masraf 46366.67 TL olarak hesaplanmıştır. Bir lisiyantus 
çiçeğinin değişken masrafi $0.17 \mathrm{TL}$, ortalama satış fiyatı $0.20 \mathrm{TL}$ ve çiçek başına brüt kâr $0.04 \mathrm{TL}$ olarak saptanmıştır. Lisiyantus üretiminde değişken masraflar içerisinde en yüksek payı \%29.96 ile kimyasal gübre masrafi almaktadır ve kimyasal gübre masrafinı $\% 24.16$ ile fide ve $\% 21.58$ ile işçilik masraflarının takip ettiği saptanmıştır. İncelenen işletmelerde yıllık ortalama 99920.06 adet kasımpatı çiçeği üretilmekte olup kasımpatı üretimindeki toplam masraf ortalama 45887.28 TL olarak hesaplanmıştır. Bir adet kasımpatı çiçeğinin değişken masrafı $0.46 \mathrm{TL}$, ortalama satış fiyatı $0.50 \mathrm{TL}$ ve çiçek başına sağlanan brüt kâr 0.04 TL olarak saptanmıştır. Kasımpatı üretiminde değişken masraflar içerisinde en yüksek payı \%31.21 ile kimyasal gübre masrafı almaktadır; kimyasal gübre masrafını \%19.05 ile organik gübre masrafının takip ettiği belirlenmiştir. İşletmelerin yıllık ortalama gerbera üretiminin 83553.06 adet ve gerbera üretimindeki toplam masrafin 37567.99 TL olduğu saptanmıştır. Bir adet gerbera çiçeğinin değişken masrafı $0.45 \mathrm{TL}$, ortalama satış fiyatı $0.49 \mathrm{TL}$ olup çiçek başına sağlanan brüt kâr 0.04 TL olarak hesaplanmıştır. Gerbera üretiminde değişken masraflar içerisinde en yüksek payı \%32.69 ile işçilik masrafı almaktadır. İşçilik masrafını ilaç (\%24) ve fide (\%16.29) masraflarının takip ettiği belirlenmiştir. Masraflar içinde en düşük payın ise $\% 1.62$ ile ambalajlama masrafina ait olduğu görülmektedir (Çizelge 4).

Çizelge 4. Kesme çiçek türlerine göre incelenen işletmelerde DM dağılımı (\%)

\begin{tabular}{|c|c|c|c|c|c|c|}
\hline \multicolumn{2}{|c|}{ Ürünler } & Karanfil & Gül & Lisiyantus & Kasımpatı & Gerbera \\
\hline \multirow{2}{*}{ Fide/ Tohum } & $\mathrm{TL} \mathrm{daa}^{-1}$ & 4000.00 & 2723.47 & 11200.0 & 2500.00 & 6118.18 \\
\hline & $\%$ & 6.94 & 6.47 & 24.16 & 5.45 & 16.29 \\
\hline \multirow{2}{*}{ Organik Gübre } & TL daa-1 & 556.190 & 844.84 & 3111.11 & 8740.05 & 814.65 \\
\hline & $\%$ & 0.97 & 2.00 & 6.71 & 19.05 & 2.17 \\
\hline \multirow{2}{*}{ Kimyasal Gübre } & TL daa-1 & 11100.00 & 11780.76 & 13888.89 & 14321.42 & 5876.26 \\
\hline & $\%$ & 19.27 & 27.99 & 29.95 & 31.21 & 15.63 \\
\hline \multirow{2}{*}{ İlaç } & TL daa-1 & 5593.33 & 7384.78 & 4444.44 & 5827.38 & 9014.43 \\
\hline & $\%$ & 9.71 & 17.54 & 9.59 & 12.70 & 24.00 \\
\hline \multirow{2}{*}{ Toprak Hazırlığı } & TL daa-1 & 2121.21 & 638.86 & 638.89 & 1121.43 & 639.47 \\
\hline & $\%$ & 3.68 & 1.52 & 1.38 & 2.43 & 1.70 \\
\hline \multirow{2}{*}{ Ambalajlama } & TL daa-1 & 1800.0 & 531.72 & 500.00 & 971.43 & 608.04 \\
\hline & $\%$ & 3.12 & 1.26 & 1.08 & 2.12 & 1.62 \\
\hline \multirow{2}{*}{ İşçilik } & TL daa-1 & 28333.33 & 16010.82 & 10000.00 & 8543.50 & 12280.30 \\
\hline & $\%$ & 49.19 & 38.04 & 21.57 & 18.62 & 32.69 \\
\hline \multirow{2}{*}{ Elektrik } & TL daa-1 & 1066.67 & 734.97 & 1027.78 & 2082.30 & 752.96 \\
\hline & $\%$ & 1.85 & 1.75 & 2.22 & 4.54 & 2.00 \\
\hline \multirow{2}{*}{ Naylon } & TL daa-1 & 1550.00 & 1442.56 & 1555.56 & 1779.77 & 1463.70 \\
\hline & $\%$ & 2.69 & 3.43 & 3.35 & 3.88 & 3.90 \\
\hline \multirow{2}{*}{ İp } & TL daa-1 & 1483.33 & 0.00 & 0.00 & 0.00 & 0.00 \\
\hline & $\%$ & 2.58 & 0.00 & 0.00 & 0.00 & 0.00 \\
\hline \multirow{2}{*}{ Toplam } & TL daa-1 & 57604.06 & 42092.78 & 46368.67 & 45887.28 & 37567.99 \\
\hline & $\%$ & 100.00 & 100.00 & 100.00 & 100.00 & 100.00 \\
\hline
\end{tabular}

İncelenen işletmelerde kesme çiçek türlerine göre brüt karlar Çizelge 5'te verilmiştir ve en kârlı kesme çiçek türü karanfil olduğu görülmektedir. Yunanistan'da Mattas et al. (2000) tarafindan yapılan bir çalışmada ise serada gül, gerbera ve helvaciotu (gypsophilla) yetiştiriciliğinin net gelirleri karşılaştırılmıştır. Menderes yöresindeki sonuçlara benzer şekilde Selanik ilindeki üreticilerden elde edilen sonuçlara göre gül yetiştiriciliğinin gerbera üretimine göre daha kârlı bir üretim dalı olduğu sonucuna ulaşmışlardır. Kızıloğlu vd. (2012) tarafindan yapılan çalışmada ise Yalova ilinde lilyum, frezya, şebboy, lisiyantus ve gül için oransal kârlar sırasıyla 0.18, 0.02, $0.08,0.02$ ve 0.04 TL olarak belirlenmiştir.

Çizelge 5. İncelenen kesme çiçek işletmelerinde BÜD, DM ve BK (TL daa-1)

\begin{tabular}{|c|c|c|c|}
\hline Ürünler & BÜD (TL daa $\left.{ }^{-1}\right)$ & DM (TL daa $\left.{ }^{-1}\right)$ & Brüt Kâr ( TL daa $\left.{ }^{-1}\right)$ \\
\hline Karanfil & 77164.87 & 57604.06 & 19560.81 \\
\hline Gül & 56637.46 & 42092.78 & 14544.68 \\
\hline Kasımpat1 & 49960.03 & 45887.28 & 4072.75 \\
\hline Lisiyantus & 56056.06 & 46366.67 & 9689.39 \\
\hline Gerbera & 40941.18 & 37567.99 & 3373.19 \\
\hline
\end{tabular}


Araştırma yöresinde işletme sahiplerinin kesme çiçek yetiştiriciliği ile ilgili görüşleri beşli likert ölçeği kullanılarak değerlendirilmiştir. Anket kapsamında görüşülen üreticilerin kesme çiçek üretimi ile ilgili görüşlerine ilişkin bazı ifadeler sorulmuştur. Üreticilerin büyük çoğunluğu "planlı bir üretim olursa plana uyarım", "kesme çiçek ile ilgili yeni öğrendiğim bilgileri seramda uygularım" ve "kesme çiçek yetiştiriciliğinden memnunum" ifadelerine önemli ölçüde katıldıklarını ifade ederken; üreticilerin yarısından fazlası çocuklarının kesme çiçek üretimini yapmalarını istememektedir ve kesme çiçek ile ilgili basılı yayınları okumadıklarını belirtmişlerdir. Üreticilerin çoğunluğu kesme çiçek üretimini azaltmayı düşünmemektedirler (Çizelge 6).

Çizelge 6. Üreticilerin kesme çiçek yetiştiriciliğine ilişkin görüşleri (\%)

\begin{tabular}{|c|c|c|c|c|c|c|}
\hline Iffadeler & 1 & 2 & 3 & 4 & 5 & Ölçek Ort. \\
\hline Planlı bir üretim olursa plana uyarım & 5.00 & 0.00 & 2.50 & 2.50 & 90.00 & 4.73 \\
\hline $\begin{array}{l}\text { Kesme çiçek ile ilgili yeni öğrendiğim bilgileri seramda } \\
\text { uygularım }\end{array}$ & 7.50 & 1.25 & 8.75 & 8.75 & 73.75 & 4.40 \\
\hline Kesme çiçek yetiştiriciliğinden memnunum & 5.00 & 7.50 & 16.25 & 6.25 & 65.00 & 4.19 \\
\hline $\begin{array}{l}\text { Kesme çiçek yetiştiriciliğinden vazgeçmeyi } \\
\text { düşünmüyorum }\end{array}$ & 18.75 & 2.50 & 20.00 & 11.25 & 47.50 & 3.66 \\
\hline $\begin{array}{l}\text { Üye olduğum çiçekçilik kooperatifinin faaliyetlerinden } \\
\text { memnunum }\end{array}$ & 12.50 & 6.25 & 26.25 & 15.00 & 40.00 & 3.64 \\
\hline $\begin{array}{l}\text { Kesme çiçekten elde ettiğim gelir ekonomik ihtiyaçlarımı } \\
\text { karşıllyor }\end{array}$ & 13.75 & 8.75 & 28.75 & 25.00 & 23.75 & 3.36 \\
\hline Kesme çiçek üretimimi artırmayı düşünüyorum & 41.25 & 1.25 & 3.75 & 3.75 & 50.00 & 3.20 \\
\hline Kesme çiçek ile ilgili basılı yayınları okurum & 60.00 & 3.75 & 7.50 & 5.00 & 23.75 & 2.29 \\
\hline Çocuklarımın kesme çiçek yetiştiriciliği yapmasını isterim & 63.75 & 2.50 & 3.75 & 6.25 & 23.75 & 2.24 \\
\hline Kesme çiçek üretimimi azaltmayı düşünüyorum & 81.25 & 0.00 & 3.75 & 2.50 & 12.50 & 1.65 \\
\hline
\end{tabular}

Üreticilerin kesme çiçek üretimine karar vermede en çok ve en az etkili olan faktörler Best-Worst analizi kullanılarak belirlenmiştir. Buna göre; üreticilerin genel olarak kesme çiçek üretimine karar vermede en çok etkili faktörler 'bu ürünü yetiştirmeye alışkın olmam' ve 'az masraflı olduğu için' iken; en az etkili faktör 'verilen desteklerden dolayı' şeklinde olarak belirlenmiştir.

Kesme çiçek türleri açısından üretim kararları incelendiğinde 'verilen desteklerden dolayı' ifadesi tüm kesme çiçek türleri için en az etkili ifade olarak tespit edilmiştir. Karanfil üreticilerini üretim kararı almalarında en çok etkileyen faktörler 'bu ürünü yetiştirmeye alışkın olmam' ve 'az masraflı olduğu içindir. Gül üreticilerinin ise en çok 'bu ürünü yetiştirmeye alışkın olmam' ifadesinden dolayı gül ürettikleri saptanmıştır. 'İşgücü ihtiyacının az olması' ifadesi lisiyantus üreticileri için en çok etkili faktör olarak belirlenirken, kasımpatı üreticilerinin üretim kararlarını en çok etkileyen faktör ise 'toprak yapısı ve iklimin bu ürünü yetiştirmeye uygun olması' olarak belirlenmiştir. Üreticilerin gerbera üretimine karar vermede ise birden fazla ifadenin eşit değere sahip olduğu görülmektedir. Araştırma sonuçlarına göre gerbera üreticilerini üretim kararı almada en çok etkileyen faktörler 'sulama imkanlarının olması', 'bu ürünü yetiştirmeye alışkın olmam' ve 'arazinin boş kalmaması' olarak tespit edilmiştir (Çizelge 7). Araştırma sonuçlarına göre 'bu ürünü yetiştirmeye alışkın olmam' yani deneyim üreticilerin üretim kararlarını etkileyen temel özellik olarak ortaya çıkmaktadır.

Çizelge 7. Kesme çiçek yetiştiriciliğine karar vermede en az ve en çok etkili faktörler

\begin{tabular}{|c|c|c|c|c|c|c|}
\hline Best / En çok etkili & Kesme çiçek & Karanfil & Gül & Gerbera & Kasımpatı & Lisiyantus \\
\hline İşgücü ihtiyacının az olması & & & & & & 0.67 \\
\hline Sulama imkânlarının uygun olması & & & & 0.18 & & \\
\hline Bu ürünü yetiştirmeye alışkın olmam & 0.28 & 0.08 & 0.31 & 0.18 & & \\
\hline $\begin{array}{l}\text { Toprak yapısı ve iklimin bu ürünü } \\
\text { yetiştirmeye uygun olması }\end{array}$ & & & & & 0.67 & \\
\hline Arazinin boş kalmaması için & & & & 0.18 & & \\
\hline Az masraflı olduğu için & & 0.08 & & & & \\
\hline \multicolumn{7}{|l|}{ Worst / En az etkili } \\
\hline Verilen desteklerden dolayı & -0.83 & -0.26 & -0.80 & -0.73 & -1.00 & -1.00 \\
\hline
\end{tabular}


Ayrıca araştırma bölgesinde kesme çiçek üreticilerine üretimde karşılaştıkları sorunlar da sorulmuştur. Kesme çiçek üreticilerinin en büyük sorunlarının başında tüm tarım ürünlerinde olduğu gibi girdi fiyatlarının yüksek olması ile ürün satış fiyatının düşük olması gelmektedir. Ayrıca üreticinin pazarda söz sahibi olamaması, kooperatif tarafından zamanında ödeme yapılmaması yani pazarlama ile ilgili sorunlar da karşılaşılan önemli sorunlardandır. Araştırma kapsamında görüşülen kesme çiçek üreticilerine, kesme çiçek üretimine ilişkin sorunların çözümüne yönelik çözüm önerileri sorulduğunda cevap veren 56 üreticinin \%48.21'i devlet desteklerinin artırılmasını ve girdi fiyatlarının düşürülmesini önermiştir. $\mathrm{Bu}$ önerileri, \%26.79 oranla pazarlama yapısının iyileştirilmesi takip etmektedir.

\section{SONUÇ VE ÖNERILER}

Araştırma sonuçlarına göre Menderes ilçesi iklim yapısı, şehir merkezine yakınlığı ve üreticilerin deneyimleriyle birlikte kesme çiçek yetiştiriciliği için uygun bir yerleşim yeri olmaktadır. Bölgede kesme çiçek üretimi yapan işletmeler, genelde küçük aile işletmeleri olarak faaliyetlerini sürdürmektedir. Üreticilerin kesme çiçek üretim deneyimleri 21-30 yıl arasındadır bu da üreticilerin uzun yıllardan beri bu işle uğraştıklarını, dolayısıyla bu konuda oldukça deneyimli olduklarını göstermektedir. İncelenen işletmelerde üreticilerin üretimini artırmayı düşündükleri ve en fazla ürettikleri ürünün gül olduğu tespit edilmiştir. Gül üretimi brüt üretim değeri açısından ikinci sıradadır. Buna rağmen üretim ve pazarlamasının kolaylığı ve fiyatının yüksek oluşu nedeniyle üreticiler tarafindan tercih edildiği saptanmıştır.

Kesme çiçek türlerinde dekara en yüksek kâr karanfil türünden elde edilirken, karanfili; gül, lisiyantus, kasımpatı, gerbera türleri takip etmektedir. Kesme çiçek türlerine göre değişiklik göstermekle birlikte; masraflar içerisinde en büyük masraf grubunu işçilik, ilaç ve gübre masrafları oluşturmaktadır. En fazla değişken masrafı olan ürün karanfil, en az değişken masrafı olan ürün ise gerberadır.

İşletme sahiplerinin kesme çiçek yetiştiriciliğinden memnun olma durumları likert ölçeğine göre ortalama 4.19 olarak hesaplanmış olup; yörede kesme çiçek yetiştiriciliğinden memnuniyet derecesinin önemli düzeyde olduğu ortaya konulmuştur.

Kesme çiçek üretimin geliştirilmesi ve verimin artırılması için üreticiler en önemli eksikliğin finansal kaynak olduğunu belirtmişlerdir. Aynı şekilde Yalova ilinde Ay (2009) tarafindan yapılan çalışmada görüşülen üreticilerin \%39.5'i finansman sorununu ilk sırada belirtmişlerdir. Ayrıca girdi fiyatlarının yüksekliği ile bazı yıllarda ürün fiyatlarının düşüklüğü üreticiler tarafindan en çok karşılaşılan sorunlar olarak belirtilmiştir.

Üreticilerin \%69.44'ü kesme çiçek üretiminin gelecekte daha iyi olacağını düşünmektedirler. Araştırma sonuçlarına göre, üreticilerin kesme çiçek sektörünü ancak örgütlenme yoluyla geliştirebileceği düşünülmektedir. Girdi fiyatlarının düşürülüp, pazarlama yapısının iyileştirilmesi için kooperatiflerin anahtar rol üstlenmesi gerekmektedir. Her ne kadar görüşülen üreticiler devletten destek beklediklerini belirtseler de üretim kararını verme açısından desteklerin hiç bir etkisi olmadığı yapılan best-worst analizi sonucunda ortaya konulmuştur. $\mathrm{Bu}$ nedenle üreticilerin doğrudan değil kooperatifler aracılığıyla desteklenmesi sektörün gelişmesine olanak sağlayacaktır.

\section{KAYNAKLAR}

Aç1l, F., Demirci, R., 1984. Tarım Ekonomisi Dersleri. Ankara Üniv. Zir. Fak. Yayın No: 880, Ankara, $298 \mathrm{~s}$.

Akkaya, F., Çakıroğlu, N., 2000. Antalya ilinde soğanlı kesme çiçek yetiştiriciliğinin mevcut durumu ve gelişme olanakları üzerinde bir araştırma. Derim, 17 (2): 54-65.

Akpınar, E., Bulut, Y., 2006. Erzurum koşullarında dikim zamanlarının bazı glayöl çeşitlerinin çiçeklenme verim ve kalitelerine etkisi. Atatürk Üniv. Ziraat Fak. Derg., 37 (2): 235-241.

Aksu, E., 2001. Bitkisel Üretim Özel İhtisas Komisyonu Süs Bitkileri Alt Komisyon Raporu. Devlet Planlama Teşkilatı, Ankara, s: 39-65.

Aksu, M., Kuşak, B., Kuşak, L., 2016. Marmara bölgesinde süs bitkileri üzerine faaliyet gösteren işletmelerin Türkiye ekonomisindeki yeri. VI. Süs Bitkileri Kongresi, Antalya, s: 105-120.

Arıkan, R., 2000. Araştırma Teknikleri ve Rapor Yazma, Gazi Kitabevi, Ankara, 65 s.

Ay, S., 2009. Süs bitkileri ihracatı, sorunları ve çözüm önerileri. Süleyman Demirel Üni. İkt. ve İdari Bil. Derg., 14 (3): 423-443.

Hazar, D., Baktır, İ., 2016. Türk karanfilinin referansı: Antalya karanfil yetiştiriciliğinin dünü, bugünü ve yarını. VI. Süs Bitkileri Kongresi, Antalya, s: 4350.

Kızıloğlu, R., Uzunöz, M., Topal, İ., 2012. Yalova İlinde Kesme Çiçek Yetiştiriciliğinin Üretim Maliyeti ve Karlılı̆̆ . Atatürk Üniv. Ziraat Fak. Derg., 43 (1): 65-68.

Mattas, K., Khaleda, K., Grafiadellis, I., Maloupa, E., Tzouramani, I., 2000. Economic Outlook of Roses, Gerbera And Gypsophila. Acta Hortic., 541, 233-240.

Newbold, P., 1995. Statistics for Business and Economics. 4. Bask1, Prentice Hall, New Jersey. $867 \mathrm{p}$. 
Özkan, B., Karagüzel, O. 1997. Kesme çiçek dışsatımında üretim ve pazarlamadan kaynaklanan sorunlar ve çözüm önerileri. I. Ulusal Süs Bitkileri Kongresi, Yalova, s: 30-45.

Taşçıŏlu, Y., Sayın, C., 2005. Türkiye'de kesme çiçek üretim ve ihracat yapısı. Akdeniz Üniv. Zir. Fak. Derg., 18 (3): 343-354.

TÜİK, 2018. Bitkisel Üretim İstatistikleri. Türkiye İstatistik Kurumu, Ankara http://www.tuik.gov.tr /UstMenu.do (Erişim Tarihi: 19 Nisan 2018).

Tutar, H. 2011. Iğdır Ovası'nda Yeni Bir Fırsat: Kesme Çiçekçilik. T.C. Serhat Kalkınma Ajansı Iğdır Yatırım Destek Ofisi, Kars, s: 13-17.
Yavuz, D.G., Miran, P.D., Özüdoğru, D.T. 2015. Türkiye'de tahıl üreticilerinin tarımsal amaçları ve üretimlerini sürdürme eğilimleri. International Conference on Eurasian Economies, KazanRussia, pp: 243-249.

Yercan, M., Kınıklı, F., 2018. Tarımsal kooperatiflerde ortakların örgütsel bağlılık düzeylerinin belirlenmesi. 6. ASM Uluslararası Tarım ve Çevre Kongresi, 11-13 Ekim 2018, Antalya, s: 455-466. 